\title{
Efficacy of epidermal growth factor receptor targeting in advanced chordoma: case report and literature review
}

\author{
Simon G Launay ${ }^{1}$, Bruno Chetaille², Fanny Medina ${ }^{3}$, Delphine Perrot ${ }^{1}$, Serge Nazarian${ }^{4}$, Jérôme Guiramand ${ }^{5}$, \\ Laurence Moureau-Zabotto ${ }^{6}$ and François Bertucci ${ }^{1,7^{*}}$
}

\begin{abstract}
Background: Chordomas are very rare low-grade malignant bone tumors that arise from the embryonic rests of the notochord. They are characterized by slow growth and long history with frequent local relapses, and sometimes metastases. While chemotherapy is not efficient, imatinib has shown antitumor activity.

Case presentation: We report on a 76-year-old patient with EGFR-overexpressing advanced chordoma that progressed on imatinib and subsequently responded to erlotinib during 12 months.

Conclusions: We report the fourth case of advanced chordoma treated with an EGFR inhibitor. We also review the literature concerning the rationale and potential of EGFR targeting in chordoma.
\end{abstract}

\section{Background}

Chordomas are very rare malignant bone tumors (approximate incidence rate 0.1/100.000/year), usually arising in the sacrum, skull base and spine. Median age at diagnosis is 60 years [1]. Originating in the embryonic rests of notochord, chordomas show a dual epithelialmesenchymal differentiation [2]. Classically, they are lowgrade malignancies characterized by slow growth and a long history with frequent local relapses. Thus, surgery is the most common treatment, followed by radiation therapy in case of non-complete resection. After a long local evolution, chordomas can also give rise to metastases (20-30\%), generally with low growth potential, primarily in the lungs, but also bones and liver. Chemotherapy has been frustratingly inactive in chordoma [1], and until recently, best supportive care was the only therapeutic option in advanced disease. However, the ongoing elucidation of the molecular mechanisms underlying chordomas has led to new therapeutic hopes. Imatinib, which blocks PDGFRs and KIT activation [3], showed antitumor activity alone [4], then in combination with cisplatin chemotherapy [5] or mTOR inhibitor [6]. Erlotinib

\footnotetext{
* Correspondence: bertuccif@marseille.fnclcc.fr

'Department of Medical Oncology, Institut Paoli-Calmettes, 232 bd SteMarguerite, Marseille, 13009, France

Full list of author information is available at the end of the article
}

(Tarceva, Hoffmann-La Roche Ltd., Basel, Switzerland) is a small molecule tyrosine kinase inhibitor targeting EGFR (epidermal growth factor receptor) in lung cancer [7]. Here, we report on a patient with EGFR-overexpressing advanced chordoma that progressed on imatinib and subsequently responded to erlotinib.

\section{Case presentation}

At first diagnosis, in 1999, the patient was a 65-year old man, Caucasian type, without any specific medical personal or familial history. His medical story began in January with chronic and rebel lumbar pain. In April 1999, pelvic magnetic resonance imaging (MRI) showed a sacral tumor. A distal sacral and coccygeal surgical resection was performed. Histological and immunohistochemical (IHC positivity for CK AE1/AE3, EMA, PS100) analyses confirmed the diagnosis of chordoma obtained by preoperative biopsy. Post-operative radiotherapy was delivered with a total dose of 60 Grays in 30 fractions.

In April 2006, computed tomography $(\mathrm{CT})$ revealed 3 subcutaneous lesions located behind the left scapula, below the right scapula, and next to the temporal bone. Two lesions (near the left scapula and temporal bone) were surgically removed, and corresponded histologically to typical relapses of chordoma. Two months later, a new recurrence was observed with a right supraclavicular 
tumor of $2 \mathrm{~cm}$, which was treated by radiotherapy (30 grays in 10 fractions).

In July 2007, a CT scan revealed disease progression with appearance of a multilocular tumor under the left scapula, several infra- and supracentimetric lung nodules suggesting metastases, and an increase in size of the right supraclavicular lesion. Once again, the two soft tissue lesions were surgically removed. Their largest pathological diameters were 9 and $5 \mathrm{~cm}$ respectively. Histological analysis confirmed the diagnosis of chordoma. Owing to the positive margins of the peri-scapular lesion, adjuvant radiotherapy was delivered (30 grays in 10 fractions), followed in October 2007 by introduction of imatinib (400 mg/day orally). Treatment was well tolerated. In February 2008, a slowly progressive subcutaneous tumor nodule located under the right scapula was surgically excised. Histological analysis again confirmed the diagnosis of chordoma. Imatinib was continued. Subsequent clinical examination and imaging monitored the stability of the disease until February 2009, at which time a CT scan showed progression at various sites: increase in size of the lung nodules, right cervical adenopathy, and two solid lesions located inside the right pectoralis minor muscle and the right paravertebral back muscle. In spite of an increased dose of imatinib (600 mg daily), the disease continued to progress slowly, even though the patient remained asymptomatic with good performance status.

Clinical examination and a CT scan in February 2010, revealed further progression, notably regarding the right cervical adenopathy $(2.2 \times 1.5 \mathrm{~cm})$ and the right pectoral lesion $(8.5 \times 4.2 \mathrm{~cm})$ (Figure 1). Clinical status deteriorated with a performance status equal to ECOG 1-2, and the appearance of a right anterior thoracic pain. Imatinib was stopped. Recent reports describing antitumor activity of EGFR inhibitors in chordoma [8-10] led us to analyze tumor samples collected from relapses excised in July 2007 and February 2008. Results were similar in both samples. Immunohistochemistry showed a strong EGFR staining in $\sim 90 \%$ of tumor cells (Figure 2). Tumor DNA was sequenced and no mutation was discovered in EGFR, KRAS, BRAF, KIT, and PDGFRA. Fluorescent in situ hybridization (FISH) did not indicate EGFR amplification, but showed chromosome 7 trisomy in 38\% of the tumor cells. Given these results and the absence of any alternative therapeutic option, in February 2010, the 76-year-old patient was started on erlotinib $150 \mathrm{mg}$ daily. After 4 weeks and no side effect, the patient reported a significant improvement of asthenia, and the thoracic pain had completely disappeared. In May 2010, after 3 months of erlotinib, the patient fared very well, the pectoral lesion had decreased, and the CT scan revealed a stabilization of the right cervical adenopathy $(2 \times 1.5 \mathrm{~cm})$ and a regression by $53 \%$ of the pectoral lesion volume $(7.6 \times$

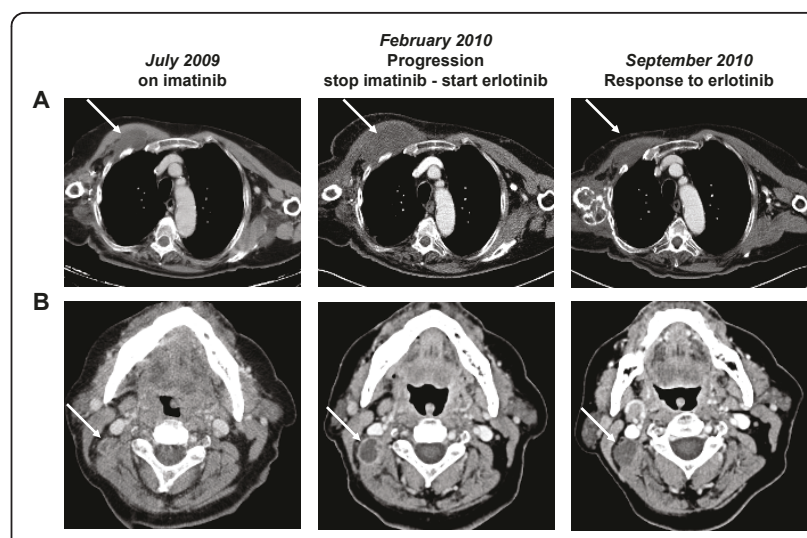

Figure 1 Cervico-thoracic CT scan showing response to erlotinib. Three different dates of treatment are shown: July 2009 (on imatinib), February 2010 (progression on imatinib; just before erlotinib), and September 2010: (response after 7 months of erlotinib). Two targets lesions are shown (arrows): the right pectoral lesion (A), and the right cervical adenopathy (B): both progressed between July 2009 and February 2010 during imatinib treatment, and responded to erlotinib between February and September 2010: regression in size of the pectoral lesion (A), and disappearance of the peripheral contrast enhancement for the adenopathy (B).

$2.3 \mathrm{~cm}$ ). Lung nodules were stable in size and number. Treatment was continued. In September 2010, a CT scan (Figure 1) showed further regression of the pectoral lesion $(6.8 \times 1.7 \mathrm{~cm}$; regression of the tumor volume by $70 \%$ when compared to February 2010). Other lesions, including the right cervical adenopathy and lung lesions, were stable. Erlotinib was continued without any significant toxicity. In February 2011, after 12 months of erlotinib, all target lesions were clinically and radiologically stable, except the right cervical adenopathy, which progressed slightly $(2.1 \times 2.8 \mathrm{~cm})$ and was treated by radiotherapy.

\section{Discussion}

There is currently no standard systemic therapy for advanced chordoma, which remains incurable. Recent

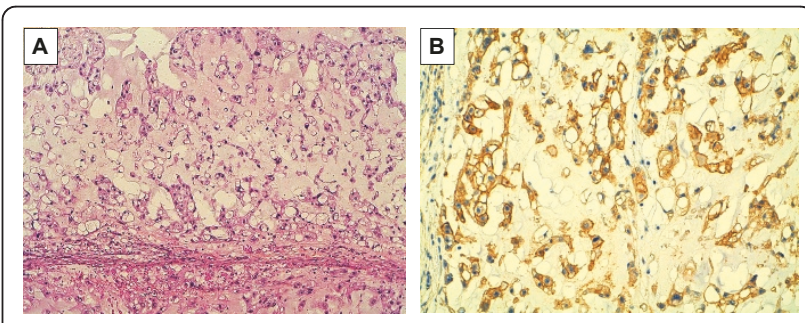

Figure 2 Chordoma and EGFR overexpression. A/H\&E staining showing round cells with vacuolated cytoplasm arranged in cordlike fashion in a myxoid stroma (original magnification $\times 100$ ). B/ Immunohistochemistry with anti-EGFR antibody showing strong membranous and cytoplasmic staining of tumor cells (original magnification $\times 200$; positivity appears in brown). 
insights into the molecular biology of the disease have led to new therapeutic hopes, particularly with the demonstration of the antitumor activity of imatinib both in vitro and in patients [3-6], and the identification of other potential therapeutic targets such as STAT3 [11], c-MET [12], and brachyury gene [13]. Our present case confirms the relative usefulness of imatinib in advanced chordoma (disease control lasting for nearly two years). More importantly, it points out the potential interest of another tyrosine kinase inhibitor, erlotinib, which resulted in an impressive clinical and radiological response lasting 12 months.

Three cases of advanced chordoma benefiting from EGFR inhibitors have been reported to date in the literature: two were treated with the gefitinib-cetuximab combination $[8,9]$, and one with erlotinib alone [10]. These cases and ours are summarized in Table 1. Despite long delays between initial diagnosis and the anti-EGFR treatment (4 years when used in first line $[8,10]$ and 11 years when used in second (our case) and third lines [9]), clinical benefits and objective tumor regressions were observed in all cases. Responses were long lasting (4+, $9+, 11+$, and 12 months), and while they primarily concerned local relapses, they also implicated lung, node, and subcutaneous metastases. In two cases, the simultaneous use of gefitinib and cetuximab obfuscated the individual anitumor contribution of each, whereas the Singhal case and ours clearly demonstrate the activity of erlotinib alone without association with the anti-EGFR antibody. Treatment was well tolerated; it was better for the case of erlotinib alone (no interruption for toxicity) than for the cetuximab-gefitinib combination (interruption lasting 2 and 4 weeks for skin toxicity). Altogether, these observations suggest that a small molecule tyrosine kinase inhibitor could very likely be sufficient.
The rationale for treating chordoma with EGFR inhibitors is inspired by recent reports. Weinberger et al showed strong and correlated IHC expression of EGFR and C-MET in a series of 12 chordomas [14]. A Polish study of 21 cases found low to high EGFR expression in $81 \%$ of cases and gene amplification in $27 \%$ of cases [15]. Activation of the EGFR signaling pathway was reported in a series of 22 clinical samples [16]. The largest series analyzed to date (173 clinical samples) confirmed frequent EGFR expression (69\%), and high-level EGFR polysomy in $38 \%$ of cases [17]. Phospho-receptor tyrosine kinase analysis showed EGFR activation in the U-CH1 chordoma cell line and all of the three chordomas analyzed. Direct sequencing of EGFR, KRAS, NRAS, HRAS, and $B R A F$ failed to reveal mutations in 62 cases. The EGFR inhibitor tyrphostin (AG 1478) inhibited proliferation of the U-CH1 cell line in vitro and diminished EGFR phosphorylation in a dose-dependant manner, a finding supported by inhibition of phosphorylated Erk1/2 and p-Akt. Altogether, these data clearly implicate aberrant EGFR signaling in the pathogenesis of chordoma. Biological analysis of our case confirmed these findings, with strong EGFR expression, and absence of gene mutation. FISH analysis revealed trisomy of chromosome 7 in $38 \%$ of tumor cells, an alteration already reported in chordomas and frequently associated with c-MET overexpression [18]. In our case, whether the trisomy of chromosome 7 is the causal mechanism of EGFR overexpression is not certain.

\section{Conclusion}

Our case highlights the antitumor activity of EGFR inhibition in advanced chordoma, in agreement with three other clinical cases previously reported and pre-clinical data. The targeting of EGFR represents an attractive

Table 1 Four patients with advanced chordoma treated with EGFR targeting therapy

\begin{tabular}{|c|c|c|c|c|c|c|c|c|c|}
\hline Ref. & Sex & $\begin{array}{l}\text { Location } \\
\text { of } \\
\text { primary } \\
\text { tumor }\end{array}$ & $\begin{array}{c}\text { Date of } \\
\text { initial } \\
\text { diagnosis }\end{array}$ & $\begin{array}{c}\text { Date of } \\
\text { beginning of } \\
\text { EGFR-targeting } \\
\text { therapy }\end{array}$ & Tumor locations & $\begin{array}{l}\text { Patient's } \\
\text { age }\end{array}$ & Therapy & Tumor response & $\begin{array}{l}\text { Duration } \\
\text { of } \\
\text { response }\end{array}$ \\
\hline$[8]$ & $M$ & Sacral & 2001 & 2005 & $\begin{array}{l}\text { Local relapse, Inguinal } \\
\text { lymph node, and lung } \\
\text { metastases }\end{array}$ & 52 & $\begin{array}{l}\text { Cetuximab- } \\
\text { Gefitinib }\end{array}$ & $\begin{array}{l}\text { «Significant regression » of all } \\
\text { lesions after } 2 \text { months* }\end{array}$ & $\begin{array}{l}\text { Ongoing } \\
\text { after } 9 \\
\text { months }\end{array}$ \\
\hline$[9]$ & $\mathrm{F}$ & Cervical & 1996 & 2007 & Local relapse & 75 & $\begin{array}{l}\text { Cetuximab- } \\
\text { Gefitinib }\end{array}$ & $\begin{array}{l}\text { Regression by } 44 \% \text { of the } \\
\text { volume after } 4 \text { months }\end{array}$ & $\begin{array}{l}\text { Ongoing } \\
\text { after } 4 \\
\text { months }\end{array}$ \\
\hline [10] & M & Sacral & 2004 & 2008 & $\begin{array}{l}\text { Gluteal mass and iliac } \\
\text { lymph nodes }\end{array}$ & 57 & Erlotinib & $\begin{array}{c}\text { Partial response superior to } 30 \% \\
\text { reduction in tumor bulk after } 3 \\
\text { months }\end{array}$ & $\begin{array}{l}\text { Ongoing } \\
\text { after } 11 \\
\text { months }\end{array}$ \\
\hline $\begin{array}{l}\text { Our } \\
\text { case }\end{array}$ & $M$ & Sacral & 1999 & 2010 & $\begin{array}{c}\text { Lung metastases, } \\
\text { cervical lymph node } \\
\text { and thoracic soft tissue } \\
\text { mass }\end{array}$ & 76 & Erlotinib & $\begin{array}{l}\text { Regression of the thoracic lesion } \\
\text { by } 53 \% \text { of the volume after } 3 \\
\text { months, by } 70 \% \text { after } 7 \text { months. }\end{array}$ & $\begin{array}{c}12 \\
\text { months }\end{array}$ \\
\hline
\end{tabular}


challenge in chordoma, which clearly calls for prospective assessment in multicentric clinical trials.

\section{Consent}

Written informed consent was obtained from the patient for publication of this case report and any accompanying images. A copy of the written consent is available for review by the Editor-in-Chief of this journal.

\section{List of abbreviations}

CT: computed tomography; EGFR: epidermal growth factor receptor; IHC: immunohistochemistry; MRI: magnetic resonance imaging; PDGFR: plateletderived growth factor receptor

\section{Acknowledgements}

Our work is supported by Institut Paoli-Calmettes and University of Mediterranea. We thank our patient who kindly gave his consent for this publication. We thank Rebecca Tagett for editing the revised version.

\section{Author details}

${ }^{1}$ Department of Medical Oncology, Institut Paoli-Calmettes, 232 bd SteMarguerite, Marseille, 13009, France. ${ }^{2}$ Department of Pathology, Institut PaoliCalmettes, 232 bd Ste-Marguerite, Marseille, 13009, France. ${ }^{3}$ Department of Radiology, Institut Paoli-Calmettes, 232 bd Ste-Marguerite, Marseille, 13009, France. ${ }^{4}$ Department of Surgery, Hopital Conception, 147 bd Baille, Marseille, 13385, France. ${ }^{5}$ Department of Surgical Oncology, Institut Paoli-Calmettes, 232 bd Ste-Marguerite, Marseille, 13009, France. ${ }^{6}$ Department of Radiotherapy, Institut Paoli-Calmettes, 232 bd Ste-Marguerite, Marseille, 13009, France. 'University of Mediterranea, 58 bd Charles Livon, Marseille, 13001, France.

\section{Authors' contributions}

Conception and design: FB; Manuscript writing: SGL and FB; Final approval: FB, SGL, BC, FM, SN, DP, JG, LMZ; Pathological explorations: BC; Patient's management: FB, SN, FM, LMZ

\section{Competing interests}

The authors declare that they have no competing interests.

Received: 9 May 2011 Accepted: 4 October 2011

Published: 4 October 2011

\section{References}

1. Casali PG, Stacchiotti S, Sangalli C, Olmi P, Gronchi A: Chordoma. Curr Opin Oncol 2007, 19:367-370.

2. Heaton JM, Turner DR: Reflections on notochordal differentiation arising from a study of chordomas. Histopathology 1985, 9:543-550.

3. Tamborini E, Miselli F, Negri T, Lagonigro MS, Staurengo S, Dagrada GP, Stacchiotti S, Pastore E, Gronchi A, Perrone F, Carbone A, Pierotti MA, Casali PG, Pilotti S: Molecular and biochemical analyses of plateletderived growth factor receptor (PDGFR) B, PDGFRA, and KIT receptors in chordomas. Clin Cancer Res 2006, 12:6920-6928.

4. Casali PG, Messina A, Stacchiotti S, Tamborini E, Crippa F, Gronchi A, Orlandi R, Ripamonti C, Spreafico C, Bertieri R, Bertulli R, Colecchia M, Fumagalli E, Greco A, Grosso F, Olmi P, Pierotti MA, Pilotti S: Imatinib mesylate in chordoma. Cancer 2004, 101:2086-2097.

5. Casali PG, Stacchiotti S, Grosso F, Messina A, Crippa F, Tamborini E, Bertieri R, Collini S, Pilotti S, Gronchi A: Adding cisplatin (CDDP) to imatinib (IM) restablishes tumor response following secondary resistance to IM in advanced chordoma. J Clin Oncol 2007, 25, 2007 ASCO Annual Meeting Proceedings, Abstract 10038.

6. Stacchiotti S, Marrari A, Tamborini E, Palassini E, Virdis E, Messina A, Crippa F, Morosi C, Gronchi A, Pilotti S, Casali PG: Response to imatinib plus sirolimus in advanced chordoma. Ann Oncol 2009, 20:1886-1894.

7. Cataldo VD, Gibbons DL, Pérez-Soler R, Quintas-Cardama A: Treatment of non-small-cell lung cancer with erlotinib and gefitinib. N Engl J Med 2011, 364:947-955
8. Hof H, Welzel T, Debus J: Effectiveness of cetuximab/gefitinib in the therapy of a sacral chordoma. Onkologie 2006, 29:572-574.

9. Linden O, Stenberg L, Kjellen E: Regression of cervical spinal cord compression in a patient with chordoma following treatment with cetuximab and gefitinib. Acta Oncol 2009, 48:158-159.

10. Singhal N, Kotasek D, Parnis FX: Response to erlotinib in a patient with treatment refractory chordoma. Anticancer Drugs 2009, 20:953-955.

11. Yang C, Schwab JH, Schoenfeld AJ, Hornicek FJ, Wood KB, Nielsen GP, Choy E, Mankin H, Duan Z: A novel target for treatment of chordoma: signal transducers and activators of transcription 3. Mol Cancer Ther 2009, 8:2597-2605

12. Ostroumov $\mathrm{E}$, Hunter $\mathrm{CJ}$ : Identifying mechanisms for therapeutic intervention in chordoma: c-Met oncoprotein. Spine (Phila Pa 1976) 2008, 33:2774-2780

13. Presneau N, Shalaby A, Ye H, Pillay N, Halai D, Idowu B, Tirabosco R, Whitwell D, Jacques TS, Kindblom LG, Bruderlein S, Moller P, Leithner A, Liegl B, Amary FM, Athanasou NN, Hogendoorn PC, Mertens F, Szuhai K, Flanagan AM: Role of the transcription factor $T$ (brachyury) in the pathogenesis of sporadic chordoma: a genetic and functional-based study. J Pathol 2011, 223:327-335.

14. Weinberger PM, Yu Z, Kowalski D, Joe J, Manger P, Psyrri A, Sasaki CT: Differential expression of epidermal growth factor receptor, c-Met, and HER2/neu in chordoma compared with 17 other malignancies. Arch Otolaryngol Head Neck Surg 2005, 131:707-711.

15. Ptaszynski K, Szumera-Cieckiewicz A, Owczarek J, Mrozkowiak A, Pekul M, Baranska J, Rutkowski P: Epidermal growth factor receptor (EGFR) status in chordoma. Pol J Pathol 2009, 60:81-87.

16. Tamborini E, Virdis E, Negri T, Orsenigo M, Brich S, Conca E, Gronchi A, Stacchiotti S, Manenti G, Casali PG, Pierotti MA, Pilotti S: Analysis of receptor tyrosine kinases (RTKs) and downstream pathways in chordomas. Neuro Oncol 2010, 12:776-789.

17. Shalaby A, Presneau N, Ye H, Halai D, Berisha F, Idowu B, Leithner A, Liegl B, Briggs TR, Bacsi K, Kindblom LG, Athanasou N, Amary MF, Hogendoorn PC, Tirabosco R, Flanagan AM: The role of epidermal growth factor receptor in chordoma pathogenesis: a potential therapeutic target. J Pathol 2011, 223:336-346.

18. Walter BA, Begnami M, Valera VA, Santi M, Rushing EJ, Quezado M: Gain of chromosome 7 by chromogenic in situ hybridization (CISH) in chordomas is correlated to c-MET expression. J Neurooncol 2011, 101:199-206.

\section{Pre-publication history}

The pre-publication history for this paper can be accessed here: http://www.biomedcentral.com/1471-2407/11/423/prepub

\section{doi:10.1186/1471-2407-11-423}

Cite this article as: Launay et al.: Efficacy of epidermal growth factor receptor targeting in advanced chordoma: case report and literature review. BMC Cancer 2011 11:423.

\section{Submit your next manuscript to BioMed Central and take full advantage of:}

- Convenient online submission

- Thorough peer review

- No space constraints or color figure charges

- Immediate publication on acceptance

- Inclusion in PubMed, CAS, Scopus and Google Scholar

- Research which is freely available for redistribution
C Biomed Central 